\title{
A study on quality of work life amongst employees working in the Kingdom of Saudi Arabia
}

\author{
Zafrul Allama* and Abdul Rahman Shaik ${ }^{\mathrm{a}}$
}

\begin{tabular}{|c|c|}
\hline CH RON I C L E & A B S T RACT \\
\hline $\begin{array}{l}\text { Article history: } \\
\text { Received: October 26, } 2019 \\
\text { Received in revised format: No- } \\
\text { vember } 212019 \\
\text { Accepted: November 23, } 2019 \\
\text { Available online: } \\
\text { November 23, } 2019\end{array}$ & $\begin{array}{l}\text { It is a well-known fact that quality of work life (QWL) is considered as a philosophy to make the } \\
\text { people more effective at workplace by understanding their psychological well-being and involve- } \\
\text { ment or attachment. The main objective of the current investigation was to understand the degree } \\
\text { of the QWL amongst the employees working in the Saudi Arabia. The random sampling method } \\
\text { was applied to select the data from employees working in the public and private sectors. The QWL } \\
\text { scale and biographical information sheet were used to gather the information from the employees. }\end{array}$ \\
\hline $\begin{array}{l}\text { Keywords: } \\
\text { QWL } \\
\text { Autonomy } \\
\text { Job satisfaction } \\
\text { Commitment } \\
\text { Relationships }\end{array}$ & $\begin{array}{l}\text { Based on the research objective and design of the investigation, factorial analysis, Cronbach's alpha } \\
\text { value for reliability check and other statistical techniques were used to explore the facts of the data. } \\
\text { The results show that six factors such as autonomy, inter-group relation, recognition, economic } \\
\text { benefits, self-respect and supervisory relations were most important determinants of QWL; married } \\
\text { and public sector employees found to have high mean score on QWL as compared with their coun- } \\
\text { terparts and majority of employees in the company were having low level of quality of work life. } \\
\text { Certain mechanism was discussed to enhance the QWL of the employees to make the organization } \\
\text { more effective and viable. }\end{array}$ \\
\hline
\end{tabular}

(C) 2020 by the authors; licensee Growing Science, Canada

\section{Introduction}

In the era of competitive environment, management and social scientists are giving more attention towards the QWL as a strategy or the philosophy to enhance the level of attachment, commitment, involvement, psychological well-being and retention of the employees. Now-a-days human resource is considered as a backbone of the organization, thereby it is required to treat these employees with full dignity and respect. The concept of "Quality of work life (QWL)" came into existence after Davis (1972) work, which has been carried out in USA. The literature available on quality of work life seems to be not too much old concept and described as the overall organizational inputs required to generate organizational effectiveness and better individual performance. QWL can be described as "overall quality of human experiences in the workplace"; can be explained that QWL is the degree of goodness in occupation and workplace conditions which might lead to holistic satisfaction of workforce; hence, the effectiveness of the organization would be established. However, QWL is varying between people to people and their understanding. Albeit, Walton (1975) conceptualized that "Quality of Work Life is the degree to which members of work organization perceive that they are able to satisfy important personal needs through their experiences in organization". Another researcher, Lippitt (1977) stated that "Quality of Work Life (QWL) as the degree to which work provides an opportunity for an individual to satisfy a wide variety of personal need to survive with some security, to interact with others, to have a sense of personal usefulness, to be recognized for achievements and to have an opportunity to improve

\footnotetext{
* Corresponding author.

E-mail address: z.allam@psau.edu.sa (Z. Allam) 
one's skills and knowledge". However, Harrison (1985) defined as "QWL is the degree to which the working organization contributes to material and psychological well-being of its members". Moreover, Sirgy et al. (2001) viewed "QWL as employee satisfaction with a variety of needs by means of resources, activities, and outcomes stemming from participation in the workplace". It is crystal clear from the above definitions that holistic understanding of the concept of QWL might enhance the effectiveness and efficiency of the organization and will contribute in achieving the specific goal.

\section{Review of Literature}

QWL has the mutual association with involvement and satisfaction (Elisaveta, 2006; Allam, 2007; Allam \& Harish 2010; Al Kahtani \& Allam, 2014; Nair \& Subash, 2019) in terms of contents of the job and working environment of the workplace. However, researchers opined that improving the QWL is an indicator to increase the efforts through motivation to accomplish the mission of the organization (Allam, 2017a) and initiate engagement techniques amongst employees for better performance to have QWL (Allam, 2017b). Quality of work life is a principle or philosophy, which describes that human resource, is one of the pillars of the organization as they are law-abiding, responsible, proficient and trust worthy thereby, they should be honored with full respect and dignity. Numerous studies have been initiated to understand QWL with different variables among employees working in various sectors (Ganapathi, 2016; Allam, 2019a; Afsar, 2014; Ali \& Zilli, 2013; Sachinidis \& Bouris, 2008). Nair (2013) suggested that QWL not only includes job satisfaction, relationship with colleagues and pay but also represents a sense of well-being that can be seen in their lives. Elovainio et al. (2005) observed that perceiving wicked QWL most likely to decrease performance and motivation and intention to leave the organization during the initial stage in their career. Nanjundeswaraswamy and Swamy (2013) carried out a study among private technical institution employees and aimed to measure QWL with the help of facets such as autonomy of work; organization culture and climate; facilities; work environment; adequacy of resources; job satisfaction \& security; compensation \& rewards; training \& development and relation \& cooperation. They revealed in their study that correlation existed between QWL of non-teaching and teaching members. Training and development and work environment were observed less related with QWL among both categories of employees whereas, adequacy of resources and compensation and rewards were found reverse i.e. more associated with QWL among two categories of staff. Ganapathi (2016) conducted a study among employees working in the construction company. He found that QWL is being influenced by salary, work environment, job security and personal growth. Thereby, he recommended that deficiency needs to be addressed to make them satisfy at workplace to perform in a lucrative manner. Many investigators found that QWL and its various facets such as working condition, capacity at work, appropriate \& fair salary, and opportunity at work have high impact on job involvement. This shows that QWL is having positive relationship with job involvement (Allam, 2007; Allam \& Ali, 2007; Hassan \& Ahmed, 2011; Al Kahtani \& Allam, 2014; Sellar \& Andrew, 2017). Usha and Rohini (2018) carried out an investigation amongst automobile companies' employee. They observed that pay and benefits, job characteristics, safe and healthy work condition, motivation and opportunity for development have impact on QWL. It is also noticed that QWL influences job satisfaction, performance and organizational commitment. Further, they revealed that QWL have more effects on job satisfaction in comparison to performance and organizational commitment. Sari et al. (2019) and Nair and Subash (2019) examined the QWL and job satisfaction among employees working in hotel industry and other sectors. Their findings revealed that QWL have positive relationship with job satisfaction. Thereby, strategists need to take initiative in advance pertaining to job satisfaction when they are making plan to enhance the QWL of the employees.

\section{Objectives of the present research:}

The following paramount aims of the current research were formulated as:

- To understand the conceptual framework of quality of work life,

- To assess the level of quality of work life of the employees in the Kingdom,

- To determine the relationships between quality of work life with various demographical variables,

- To develop some theoretical framework to support the future research by aligning quality of work life and biographical variables.

\subsection{Hypotheses of the investigation}

Based on the retrospection of the review of literature and keeping in mind the main goals of the inquisition, the following null hypotheses were formulated:

Ho1: Married and unmarried employees would not be differing on QWL.

Ho2: There would not be significant difference on QWL between employees of public and private sectors.

\subsection{Research Methodology}

Sample: The sample of the current investigation comprises of total 148 employees working in both public and private sectors in Kingdom of Saudi Arabia. The respondents were randomly selected for this investigation. 
Shawkat and Ansari (2001) standardized and developed QWL scale was used to collect the perceptions of the respondents. This particular tool evaluates many facets related to QWL such as work itself; organizational climate; employees' participation; physical working condition; union management relations; self-respect; organizational commitment; promotion; clarity at organization; employee health; inter-group relation (employee's relations); autonomy at work; supervisory relations; economic benefits and recognition. The total items were 48 and respondents are required to provide their feelings on five-point rating scale as below

"1- High disagreement"

"2-Disagreement"

"3- Neutral"

"4- Agreement"

"5- Strongly agreement"

The total score of this scale will be varying from 48-240. Higher the score reflects high QWL and vice-versa. The reliability and validity of the scale observed to be .70 and .89 respectively which means scores are highly significant. Also, demographical characteristics obtained with the help of biographical information blank from the respondents such as nationality, gender, age etc.

\section{Procedure}

The investigators distributed the questionnaire and collected data from each respondent personally. The whole instruction was given to the respondents before filling the questionnaire. The actual responses received were 75 , while the sample size was increased to 148 by adopting random techniques due to data insufficiency. All ethical procedures were established. The collected data were coded by the investigators with the help of scoring key of the scale.

Data collection and analysis: To achieve the planned objectives, appropriate statistical techniques were applied to analyze the data. Descriptive and inferential statistical methods were used to analyze the data.

\section{Results and Discussion}

Fig. 1 demonstrates the results of the personal characteristics of the participants in our survey. As we can observe from the figure, $48.7 \%$ of the respondents belong to the public sector, while $51.3 \%$ of employees are from private sector. In addition, the majority of the respondents $(91.2 \%)$ are non-Saudi residence and only $8.8 \%$ of them were Saudi Arabia citizen. In our survey, most participants were male (98\%) and their income was less than 10,000 Saudi currency. While over $70 \%$ of the participants were married, most participant were either young or middle age. Finally, our survey indicates that most participants hold university educations. Table 1 demonstrates the results of KMO and Bartlett's tests.

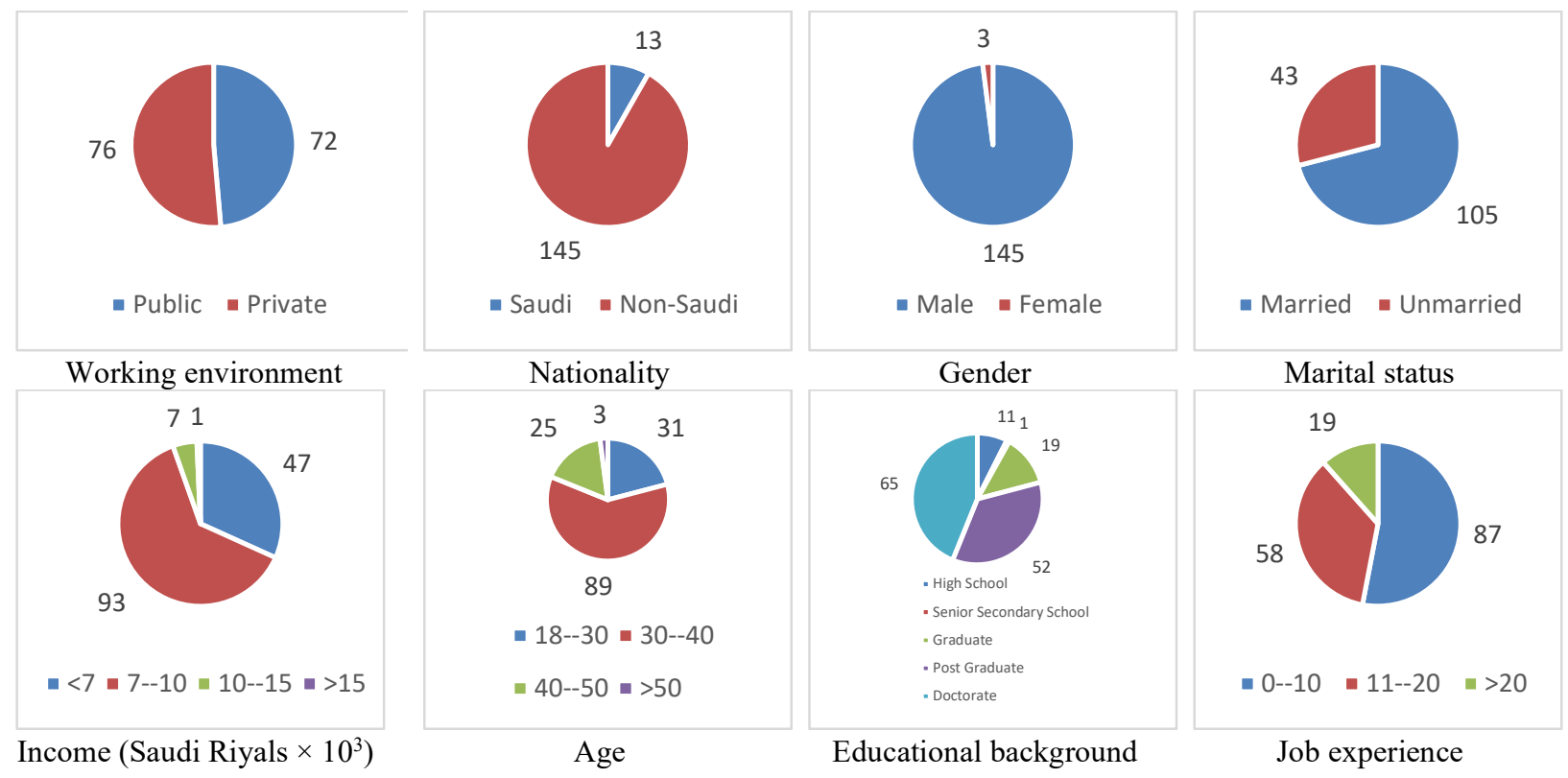

Fig. 1. Personal characteristics of the participants 
According to Table 1, Bartlett's test of sphericity is found to have a high Chi-Square value which is significant as the value $\mathrm{p}<0.001$. It is observed that facets or factors are responsible to generate QWL among the employees. Indeed, the robustness of the current investigation has motivated us to do factorial analysis to check the factors responsible for accomplishment of QWL. The KMO value was .759, which indicates the significance level that might be useful to analyze with the help of factor analysis. Table 2 demonstrates the results of our survey.

Table 1

Exhibiting the KMO and Bartlett's Test

Kaiser-Meyer-Olkin Measure of Sampling Adequacy.

Bartlett's Test of Sphericity

$\begin{array}{ll} & .759 \\ \text { Approx. Chi-Square } & 1.544 \mathrm{E} 3 \\ \text { df } & 210\end{array}$

Sig.

.000

Table 2

Exhibiting the factor loading in terms of Rotated Component Matrix

\begin{tabular}{|c|c|c|c|c|c|c|}
\hline \multirow[t]{2}{*}{ Statements } & \multicolumn{6}{|c|}{ Factors } \\
\hline & 1 & 2 & 3 & 4 & 5 & 6 \\
\hline Statement 17 & .742 & & & & & \\
\hline Statement 18 & .828 & & & & & \\
\hline Statement 23 & .418 & & & & & \\
\hline Statement 29 & .668 & & & & & \\
\hline Statement 6 & & .821 & & & & \\
\hline Statement 34 & & .788 & & & & \\
\hline Statement 37 & & .515 & & & & \\
\hline Statement 4 & & & .510 & & & \\
\hline Statement 10 & & & .872 & & & \\
\hline Statement 44 & & & .477 & & & \\
\hline Statement 24 & & & & .543 & & \\
\hline Statement 43 & & & & .677 & & \\
\hline Statement 3 & & & & & .693 & \\
\hline Statement 19 & & & & & -.834 & \\
\hline Statement 15 & & & & & & .456 \\
\hline Statement 26 & & & & & & .804 \\
\hline Cronbach's alpha & .761 & .688 & .677 & .461 & .949 & .572 \\
\hline Initial Eigen values & 7.305 & 2.090 & 1.484 & 1.303 & 1.073 & 1.011 \\
\hline$\%$ of Variance & 34.786 & 9.955 & 7.065 & 6.205 & 5.112 & 4.814 \\
\hline Cumulative \% & 34.786 & 44.740 & 51.805 & 58.010 & 63.122 & 67.936 \\
\hline
\end{tabular}

Notes: Extraction Method: Principal Component Analysis

Rotation Method: Varimax with Kaiser Normalization.

Rotation converged in 7 iterations.

It is observed that six factors obtained with Eigen values over 1.0 as 7.305, 2.090, 1.484, 1.303, 1.073 and 1.011 along with 67.936 per cent of total variance. Criterion .40 is aforethought as stipulated deciding factor in loading (Ford et al., 1986; Hinkin, 1995). Further, Nunnally (1978) opined that .7 or more alpha values are acceptable value but in our case except one item, all other factors have less than .7 which is also acceptable (Bretz, \& McClary, 2014; Griethuijsen et al., 2014).

Factor 1 (Autonomy): This factor loaded on four items which represented participation in decisions and improve the conditions, working atmosphere supportive and allow to give suggestions. It is inferences that these items reflect about the freedom at workplace and hence termed as "Autonomy".

Factor 2 (Inter-group relation): This factor loaded on three items and representing cooperation, positive opinion for others and concern to achieve the goals. These items are more likely seems to be associated with relationship and it is designated as "Inter-group relation".

Factor 3 (Recognition): This factor loaded on three items and represented encouragement from supervisor to enhance the performance, sense of achievement and quality of life. It can be drawn on the basis of results of these items that it is well related to recognition and hence is nominated as "Recognition".

Factor 4 (Economic benefits): This factor loaded on two items and represented performance is highly appreciated for vertical growth and saving plan. Therefore, this factor is termed as "Economic benefits". 
Factor 5 (Self-respect): This factor loaded on two items and represented feeling about the job and respect. Hence, this factor is called as "Self-respect".

Factor 6 (Supervisory relations): This factor loaded on two items and represented supervisor allowed them to give feedback \& respect and treatment. Therefore, this factor is represented as "Supervisory relations".

Table 3

Mean, SD's and t-value of married and unmarried sector of employees on total QWL

\begin{tabular}{ccccc}
\hline Groups Compared & $\mathrm{N}$ & Mean(TQWL) & Std. Deviation & t-value \\
\hline Married & 105 & 184.83 & 23.209 & $4.42^{* *}$ \\
Unmarried & 43 & 166.40 & 22.627 & \\
\hline
\end{tabular}

Significant at $* * \mathrm{P}<.01$

Significant at $* \mathrm{P}<.05$

Table 3 reveals that married group of employees found to have high mean score on QWL as compared with unmarried group. The result displays that mean quality of work life of married and unmarried groups of employees were found to be $184.83 \&$ 166.40 with sd., $23.209 \& 22.627$, respectively. The calculated value related to " $t$ " was observed 4.42 , which is significant at .01 levels and henceforth, the proposed null hypothesis $\left(\mathrm{H}_{1}\right)$ was rejected. Islam et al. (2012) and Osibanjo et al. (2019) supported our findings and mentioned that married employees are having more responsibilities, commitment and involvement as compared to those who are still bachelor; such attributes reflects the establishment of QWL.

Table 4

Mean, SD's and t-value of public and private employees on total QWL

\begin{tabular}{cccc}
\hline Groups Compared & $\mathrm{N}$ & Mean(TQWL) & Std. Deviation \\
\hline Public & 72 & 182.93 & 21.532 \\
Private & 76 & 176.20 & 26.656 \\
\hline
\end{tabular}

It is emerged from Table 4 that public sector employees found to maintain high mean score on QWL as compared with private sector employees. The result displays that mean quality of work life of public and private groups of employees were found to have mean of 182.93 and 176.20 as well as the standard deviation of 21.532 and 26.656 , respectively. The calculated value related to "t" was observed 1.68; considered not significant at any level and hence, the proposed null hypothesis $\left(\mathrm{H}_{2}\right)$ was accepted. Padhy and Bhuyan (2015) observed that job satisfaction as a component of quality of work life to be low among private sector employees due to several reasons such as salary, job security etc., and their finding is against our findings. The current findings were supported by Ahsan (2017).

Table 5

The results of regression estimate

\begin{tabular}{|c|c|c|c|c|c|c|c|c|}
\hline \multirow[t]{2}{*}{ Model } & & \multicolumn{2}{|c|}{ Unstandardized Coefficients } & \multirow{2}{*}{$\frac{\text { Standardized Coefficients }}{\text { Beta }}$} & \multirow[t]{2}{*}{$\mathrm{t}$} & \multirow[t]{2}{*}{ Sig. } & \multicolumn{2}{|c|}{ Collinearity Statistics } \\
\hline & & B & Std. Error & & & & Tolerance & VIF \\
\hline \multirow{6}{*}{1} & (Constant) & 1.430 & 1.152 & & 1.241 & .217 & & \\
\hline & FAC2 & .216 & .084 & .186 & 2.573 & .011 & .801 & 1.248 \\
\hline & FAC1 & .082 & .055 & .119 & 1.474 & .143 & .638 & 1.566 \\
\hline & FAC4 & .354 & .103 & .254 & 3.428 & .001 & .761 & 1.314 \\
\hline & FAC5 & .231 & .111 & .145 & 2.085 & .039 & .871 & 1.149 \\
\hline & FAC6 & .297 & .102 & .236 & 2.922 & .004 & .643 & 1.555 \\
\hline
\end{tabular}

a. Dependent Variable: QWL

Diagnostic Tests:

R Square -0.41

Adjusted R Square -0.38

F-statistic - $19.36(0.000)$

DW test statistic -1.95

The study has estimated a regression, by considering statements of factor 3 viz., 4, 10 and 44 as a dimension of QWL (which is a Dependent Variable) and the other factors as explanatory variables. The study has selected factor 3 (Recognition) as a dependent variable, since it is one of the important dimensions of QWL. The other factors, such as factor 1,2,4,5 and 6 are the various determinants that explain the QWL in an organization. The current study estimated a regression to examine the significance of these determinants in explaining the QWL. The estimated regression is explained in Eq. (1) below.

$$
Q W L_{i}=\propto_{i}+\beta_{1} f a c 1_{i}+\beta_{2} f a c 2_{i}+\beta_{3} f a c 4_{i}+\beta_{4} f a c 5_{i}+\beta_{5} f a c 6_{i}+\varepsilon_{i}
$$

where $\propto_{i}$ is the constant; $Q W L_{i}$ is a dependent variable considered from the statements of factor 3 ; fac 1 consists of the statements 17, 18, 23 and 29; fac2 consists of the statements 6, 34 and 37; fac4 consists of the statements 24 and 43 ; fac5 consists of the statements 3 and 19 and $f a c 6$ consists of the statements 15 and 26, while $\varepsilon$ represents the error term. Moreover, this particular model is diagnosed with the help of R-Square, F-statistic, and Durbin-Watson test statistic. 
The following are the results of equation estimated above.

The results of Eq. (1) are reported in Table 5. The results show that, among all explanatory variables, i.e. factors, all the factors are meaningful when the level of significance is $5 \%$ except fac1, which is insignificant. It can be observed from the above results that, all the statements included in different factors explain the QWL in an organization except the statements of factor 1 and these factors shall be treated as the determinants that explain the QWL. The model summary shows an adjusted R Square of $38 \%$, a significant F-statistic at less than 0.01 level of significance and Durbin-Watson test statistic less than 2. The diagnostic tests show that the estimated equation is a good model of fit and there is no multi-collinearity among the explanatory variables included in the equation.

Table 6

The level pertaining to overall quality of work life (QWL)

\begin{tabular}{ccc}
\hline Level of QWL & No. of Respondents & Percent \\
\hline High & 50 & 33.8 \\
Moderate & 34 & 23.0 \\
Low & 64 & 43.2 \\
\hline
\end{tabular}

According to Table 6, it is crystal clear that the majority of employees in the company felt low level of QWL (N=64, 43.2\%) followed by $23 \%(\mathrm{~N}=34)$ moderate level of QWL and high level of QWL showed by $33.8 \%(\mathrm{~N}=50)$. Kelbiso et al. (2017) also observed that the majority of the employees prone towards low level of QWL and supported our findings. Other researchers also pointed that most of the employees were dissatisfied with facilities and hence indicated that the majority of the workforce were having low QWL (Almalki et al., 2012). Whereas, Erdem (2014) observed that medium level of QWL employees have low level of alienation. But, Alzalabani (2017) and Subbarayalu and Al Kuwaiti (2019) revealed that majority of the people perceived high level of QWL which is against our findings.

\section{Conclusion}

The following conclusions were drawn based on the findings:

- Six factors; namely autonomy, inter-group relation, recognition, economic benefits, self-respect and supervisory relations are responsible in generating the QWL among employees.

- Married group of employees found to maintain high mean score on QWL as compared with unmarried group.

- Private sector employees found to maintain less mean score on QWL as compared with public sector employees.

- The diagnostic test shows that the estimated equation is a good model of fit and there is no multi-collinearity among the explanatory variables included in the equation.

- Majority of employees in the company felt low level of QWL followed by moderate level and high level of QWL.

\section{Suggestions and limitation}

Human resource progress is important and vital since human capital is an important asset of the organization; thereby, retaining and maintaining their competencies is also the priority of the management to provide QWL at workplace. From the findings, it is observed that six factors were obtained such as autonomy, inter-group relation, recognition, economic benefits, selfrespect and supervisory relations responsible to have quality of work life. Furthermore, majority of the employees felt low level of QWL at workplace. Indeed, QWL was related to improve the performance (Sari et al., 2019), satisfaction (Chaturvedi \& Yadav, 2011, Allam, 2013), job involvement (Allam, 2007), commitment (Ali \& Zilli, 2013; Allam, 2013), work motivation (Sari et al., 2019; Robbins, 2003, Allam, 2017a), adoption of fair HRM practices (Al Kahtani et al., 2016; Allam, 2019b). Thereby, we must develop appropriate strategies to act on above variables to maintain and enhance the QWL of the employees. In addition to these, management must enrich the work atmosphere, provide adequate training to enhance the skills, provide opportunities for growth \& development, allow employees to participate in decision making processes, develop sense of ownership, give reward (financial \& non-financial), provide assurance of job security and flexible working time since these factors are more prone to create quality of work life at workplace among workforce. Like other investigation, every research is considered as continuous learning process and exploring to establish conceptual framework including methodological understanding with the help of limited resources and stipulated time periods. Therefore, this research has also certain limitation but left scope for further future researches and allowed other investigators to investigate similar kinds of study by taking different variables, tools, samples and statistical techniques to get viable or scientific results with more authenticity.

\section{Acknowledgements}

The Deanship of Scientific Research at Prince Sattam Bin Abdulaziz University supported this project under the research project number \# 2019/02/10114. So, we express our sincere gratitude to the university for the financial support. 


\section{References}

Afsar, S.T. (2014). Impact of the quality of work life on organizational commitment: A comparative study on academicians working for state and foundation university in Turkey. International Journal of Social Sciences, 3(4), 124-152.

Ahsan, M.K. (2017). A comparison of job satisfaction of private and public banks employees. Journal of Studies in Management and Planning, 3(6), 76-92.

Al Kahtani, N.S., \& Allam, Z. (2014). The influence of job burnout, involvement and locus of control on job satisfaction: some explorations from banking sector in Saudi Arabia. New York Science Journal, 7(2), 93-101.

Al Kahtani, N.S., Nawab, A. K., \& Allam, Z. (2016). Unfair HRM practices in the telecom sector in Saudi Arabia. An empirical investigation of selected public and private sector companies. International Journal of Applied Business and Economic Research, 14(10), 6377-6396.

Ali, A. \& Zilli, A.S. (2013). Job attitude and quality of work life as a predictor of organizational commitment: A study of managers. TRANS Asian Journal of Marketing and Research, 2(10), 14-17.

Allam, Z. (2017b). Employee disengagement: A fatal consequence to organization and its ameliorative measures. International Review of Management and Marketing, 7(2), 49-52.

Allam, Z. (2019a). An inquisitive enquiry of work-life balance of employees: Evidences from Kingdom of Saudi Arabia. Management Science Letters, 9(2), 437-444. 339-346.

Allam, Z., \& Ali, N. (2007). Job involvement, job anxiety and job burnout: a comparative study of bank employees. Social Sciences International 23(1)35-44.

Allam, Z. (2007). A study of relationship of job anxiety and job burnout with job involvement among bank employees. Management and labor studies, 21(1) 30-38.

Allam, Z. (2013). Job anxiety, organizational commitment and job satisfaction: An empirical assessment of supervisors in the state of Eritrea. International Journal of Development and Management Review, 8, 50-62.

Allam, Z. (2017a). Intrinsic and extrinsic motivation: An empirical tale of employees looks in a job. Research Journal of Applied Sciences, 12(2), 117-124.

Allam, Z. (2019b). Exploring ambient discriminatory HRM practices: An insight from Kingdom Telecom Company. The Journal of Social Sciences Research, 5(3), 646-654.

Allam, Z., \& Harish, K.T. (2010). Influence of sociodemographic factors on job burnout and satisfaction among Eritrean medical workers. Nigerian Journal of Psychiatry, 8(1), 43-47.

Almalki, M. J., FitzGerald, G., \& Clark, M. (2012). Quality of work life among primary health care nurses in the Jazan region, Saudi Arabia: a cross-sectional study. Human Resources for Health, 10(1), 30.

Alzalabani, A.H. (2017). A study on perception of quality of work life and job satisfaction: evidence from Saudi Arabia. Arabian Journal of Business and Management Review, 7(2), 1-9. doi: 10.4172/2223-5833.1000294

Bretz, S. L., \& McClary, L. (2014). Students' understandings of acid strength: how meaningful is reliability when measuring alternative conceptions? Journal of Chemical Education, 92(2), 212-219.

Chaturvedi, V., \& Yadav, D.S. (2011), A study on impact of job satisfaction on quality of work life among employees in hotel industry (with reference to categorized hotels in Faridabad region). International Journal of Research in Computer Application \& Management, 1(4), 101-104.

Davis, L.E. (1972). Paper presented at International conference. Arden House, Hariman New York, September, 25-29.

Elisaveta, S. (2006). Relationship among perception of quality of work life and job satisfaction. Management and Organizational Review, 2(3), 459- 460.

Elovainio, M., Forma, P., Kivimäki, M., Sinervo, T., Sutinen, R., \& Laine, M. (2005). Job demands and job control as correlates of early retirement thoughts in Finnish social and health care employees. Work \& Stress, 19(1), 84-92.

Erdem, M. (2014). The level of quality of work life to predict work alienation. Educational Sciences: Theory \& Practice, 14(2), 534-544.

Ford, J. K., MacCallum, R. C., \& Tait, M. (1986). The application of exploratory factor analysis in applied psychology: A critical review and analysis. Personnel Psychology, 39, 291-314.

Ganapathi, R. (2016). A study on quality of work life in construction industry in Madurai district. Journal of Management Research and Analysis, 3(2), 63-66.

Griethuijsen, R. A., van Eijck, M. W., Haste, H., den Brok, P. J., Skinner, N. C., Mansour, N., ... \& BouJaoude, S. (2015). Global patterns in students' views of science and interest in science. Research in science education, 45(4), 581-603.

Harrison, T. M. (1985). Communication and participative decision making: An exploratory study. Personnel Psychology, 38(1), 93-116.

Hassan, A. \& Ahmed, F. (2011). Authentic leadership, trust and work engagement. International Journal of Human and Social Sciences, 6(3), 164-170.

Hinkin, T. R. (1995). A review of scale development practices in the study of organizations. Journal of Management, 21(5), 967-988.

Islam, M.Z., Hasan, I., \& Zain, A.Y.M. (2012). Organizational culture and structure on knowledge sharing. available at: http://ssrn.com/abstract $=2180427$

Kelbiso, L., Belay, A., \& Woldie, M. (2017). Determinants of quality of work life among nurses working in Hawassa Town Public Health Facilities, South Ethiopia: A cross-sectional study. Nursing Research and Practice, 1-12. https://doi.org/10.1155/2017/5181676 
Lippitt, G.L. (1977). Quality of work life: organizational renewal in action. Training and Development Journal, 32(7), 4-11.

Nair, P.R. \& Subash, T. (2019). Quality of work life and job satisfaction: A comparative study. International Journal of Business and Management, 8(2), 15-21.

Nair, G.S. (2013). A study on the effect of quality of work life (QWL) on organizational citizenship behavior (OCB)- with special reference to College Teachers is Thrissur District, Kerala. Integral Review- A Journal of Management, 6(1), 3446.

Nanjundeswaraswamy, T.S. \& Swamy, D.R. (2013). Quality of work life of employees in private technical institutions. International Journal of Quality Research, 7(3), 3-14.

Nunnally, J. C. (1978). Psychometric theory. McGraw-Hill, New York.

Osibanjo, A. O., Waribo, Y. J., Akintayo, D. I., Adeniji, A. A. \& Fadeyi, O. I.(2019). The effect of quality of work life on employees' commitment across Nigerian tech start-ups. International Journal of Mechanical Engineering and Technology, 10(3), 41-59.

Padhy, K.P. \& Bhuyan, J. (2015). Determinant of job satisfaction in public and private sector: an empirical study. International Journal of Engineering Technology, Management and Applied Sciences, 3(1), 70-81.

Robbins, S. (2003). Perilaku Organisasi. Jakarta: PT INDEKS kelompok GRAMEDIA.

Sachinidis, A.G. \& Bouris, J. (2008). Employee perceived training effectiveness relationship to employee attitudes. Journal of European Industrial Training, 32(1), 63-76.

Sari, N.P.R.; Bendesa, K.G., \& Antara, M. (2019). The influence of quality of work life on employees' performance with job satisfaction and work motivation as intervening variables in star-rated hotels in Ubud tourism area of Bali. Journal of Tourism and Hospitality Management, 7(1), 74-83.

Sellar,T., \& Andrew, A.(2017). The impact of quality of work life on job involvement of auto mechanic employees. International Journal of Research, 4(8), 1294-1304.

Shawkat, S. \& Ansari, S.A. (2001). Organizational commitment scale. Unpublished doctoral thesis, Aligarh Muslim University, India.

Sirgy, M., Efraty, D., Siegel, P. \& Lee, D.J. (2001). A new measure of quality of working life (QWL) based on need satisfaction and spillover theories. Social Indicators Research, 55,241-302.

Subbarayalu, A.V. \& A1 Kuwaiti, A. (2019) Quality of work life of teaching staff working at a higher education institution in Saudi Arabia: A cross-sectional Study. Journal of Social Service Research, 45(4), 530-542.

Usha, S., \& Rohini, V. (2018). Impact of quality of work life on work outcome of employees in automobile companies in Chennai. International Journal of Pure and Applied Mathematics, 118(20), 787-799.

Walton, R.E. (1975). Criteria for quality of working life. In Davis, L.E. and Cherns, A.B. (eds.) The quality of working life, Vol. 1: Problems, Prospects and the state of the art, New York: The Free Press.

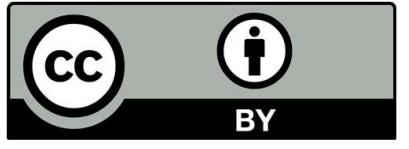

(C) 2020 by the authors; licensee Growing Science, Canada. This is an open access article distributed under the terms and conditions of the Creative Commons Attribution (CC-BY) license (http://creativecommons.org/licenses/by/4.0/). 